\title{
Evaluating Socio-Economic and Environmental Impacts of Utilization of Renewable Energy Sources in Iran
}

\author{
Samaneh Falaki \\ Master of Environmental Assessment and Land Use \\ Planning \\ University of Birjand \\ Birjand, Iran
}

\author{
Mahmood Zohoori \\ Master of Environmental Management \\ UPM \\ Birjand, Iran
}

\begin{abstract}
Renewable energy sources is a quickly spreading field which has changed significantly over recent years. Besides advancement in technologies of renewable energy sources lead to the production of clean energy in a wide scale. Furthermore, renewables can be an origin of jobs and economically origin of energy. On the other words, nowadays, fossil fuels are the principal energy sources in which electricity is obtained. However, these sources will not last forevermore, and thus in due course renewable energies will have to sub them in this role. All kinds of energy sources have some negative effects on our environment. Fossil fuels coal, oil, and natural gas - are considerably more detrimental than renewable energy sources by most measures, including pollution of water and air, public health damage, loss of habitat and wildlife, water usage, land utilization, and global warming emissions. Besides regarding social impacts of utilization of renewables is job creation, economics, health, and oil dependence. The goal of this article is to examine and evaluate impacts of utilization of renewable energy sources on socio-economic and environmental status which are able of being renewed if consume properly with the aim of choosing suitable and passable resources of energy as for achieving various policy's intentions and purposes in Iran. On the other hand, this research highlights social, economic and environmental impacts of these resources and after that proposes an appropriate techniques to rank them.
\end{abstract}

Keywords: Renewable Energy, Iran, Social, Environment, Economics, Energy, Clean Energy, Renewables, global Warming Emissions, land and Water Use, Job Creation, Health, Oil Dependence, Iran

\section{INTRODUCTION}

Nowadays, all states and governments in all countries are concentrating on topics which are concerning about environments. In association with the point formerly mentioned, all governments are obliged to evaluate the purpose and aim of socio-economic as well as needed and mandatory energies.

Based on international outlook, International Energy Agency (IEA) (2004) declared that energy that is mighty of being renewed is tested by large number of policy-makers in countries that are members of IEA as a tool to chip in develop environmental protection, economic development, energy security recognized as 3 Es. Supposing Ireland as an example. Komor and Bazilian (2005) asserted which many people who drive and stimulate Irish policy about energy that are capable of being renewed can be categorized and settled into energy's purpose, goals retaining to environment and socio-economic / industrial purposes.

Likewise, approximately all of the countries are ensured which those policies that regard energy as able of being renewed must be capable to get each of $3 \mathrm{E}$ goals, and objects (Shen et al, 2010). There are some studies have displayed specific policies' goal that regard energy as able of being renewed takes one to specific sources and technologies as for renewable energy (Beccali et al., 2003; Komor and Bazilian, 2005; Onut et al., 2008).

There are a great amount of complex logical methods to be utilized in order to quest for the most desirable response for multi-purpose obstacles (Greening and Bernow, 2004). One of the most markedly and excellently used methods and procedures is the analytic hierarchy process (AHP) found and established by Saaty (1980). Nevertheless, uncertainty and lack of clarity in many examples is found between the assessments of decision-makers concerning the problems that they look for to deal with. Fuzzy combines with AHP to form fuzzy AHP recognized as FAHP and is employed to examine and weigh the uncertainty and lack of clarity which exists in the valuation of decision-makers subjective.

Industrial and technological improvement resulted in development in living standard and much more energy requesting life. By ongoing rise in energy consumption rates, energy supply will be an actual challenge in a near future for the entire globe and even for the countries which are rich in oil at present. The world energy production rate was 1.65 (ton $\mathrm{oE}$ ) and 1.82 (ton oE) per capita in 2000 and 2007 respectively, demonstrating growth rate of 10.3 percent (Iran's Ministry of Energy, 2008).

Accordingly, there are a lot of countries that have paid great amounts of money for consideration to use alternative energy resources particularly, the renewables to meet their ever growing energy demands. These countries also have taken actions in improvement and usage of renewable energy technologies to get sustainable development. Moreover, these efforts will also decrease emissions of the greenhouse gases which is one of the current and main environmental problems.

Taking into consideration that the main component of greenhouse gases (GHGs) is carbon dioxide, there is a universal concern regarding diminishing carbon emissions. In this regard, various policies can be applied to decrease carbon emissions, such as boosting renewable energy deployment and cheering technological innovations. Plus, supporting mechanisms, for example, feed-in tariffs, renewable portfolio standards and tax policies, are employed by states to improve the generation of renewable energy along with implementing energy usage performance and efficiency for saving energy (Abolhosseini et al, 2014).

Iran's energy security is based on oil, it means the preliminary source of energy is oil in Iran. In 2000, the production of 
energy was 1.84(tons oE) per capita. This amount has been expanded to 2.6(ton oE) in 2007 which demonstrates $41 \%$ rise in the rate of energy production. In accordance with the progressive rate, energy production is expected to reach around 4 (ton oE) per capita by 2020 due to socio-economic and ecological improvement, as well as progression of the life standards (Zohoori et al, 2012).

Iran makes a profit from a lot of sources of fossil fuel in the form of natural gas or oil reservoir in the region. The reality is that $18.2 \%$ of oil reservoir and $30.5 \%$ of natural gas reservoir belongs to Iran. Consumption of energy departments in Iran, use energy in the form of electricity, natural gas or oil, with extremely high subsidized costs for many years. For instance, actual worth for natural gas is 6.60 cents $/ \mathrm{m} 3$ while in Iran with subsidized prices it decreases to 0.85 cents $/ \mathrm{m} 3$. Electricity follows the same trend too. For example, Electricity is supplied for use of household users, agricultural and industrial segments with the average subsidized value of 1.65 cents $/ \mathrm{kWh}$ while according to Iran's ministry of energy 2008 , the actual price is 7.36 cents $/ \mathrm{kWh}$. Hence, natural gas and electricity are given with approximate $13 \%$ and $29 \%$ of their genuine prices and this matter is the leading obstacle for expansion and utilization of renewable energy. Besides, there is absence of determination and ambition amongst the users of energy as well as inadequate publicity and rationalization of renewable energy technologies by government circle and media which restricts the application of such green energy resources between all users. Lately, the Iran's government has begun a strategy to delete subsidies for both fuel energy production and electricity, and Iran's parliament has ratified it. Implementation of such strategy will bring about a sharp increase in the energy costs and subsequently will boost production prices too. Thus, inquiry and utilization of renewable energy sources and its relevant technologies in order to avoid prices rise. That's why propagation and promotion of socio-economic growth is an inescapable challenge in near future (Zohoori et al, 2012).

Newly, the major universal challenges of governments are including the diminishing and lessening of climate changes as well as consumption of fossil fuels (Shen et al.2010). Many countries are doing investigations to create and enhance sources of energy which can be retrieved and refreshed in order to get these challenges. Iran, as a country located in Middle East, seeks energies which can be restored and refreshed to meet the challenge of the numerous rate of carbon emissions too (Zohoori et al, 2012).

This paper try to highlight major sources of renewable energies in Iran as well as their positive effects on socioeconomic and environmental conditions in Iran too. Besides, the research offers a proper technique to rank them.

\section{LITERATURE REVIEW}

There are too many researches regarding meeting up with 3 Es, and abundant researchers and scholars have emphasized various standards and measures for this. Amongst all scholars, Shen et al. (2010) and Komor\& Bazilian (2005) are the most famous and cherished ones.

In the research carried out by Komor \& Bazilian (2005), they interpreted the connection and relation between renewable energy programs, 3 Es attempts and purposes and encouragement for techniques of energies that can be restored and refresh as below:

Figure 1: P. Komor, M. Bazilian / Energy Policy 33 (2005) 1873-1881

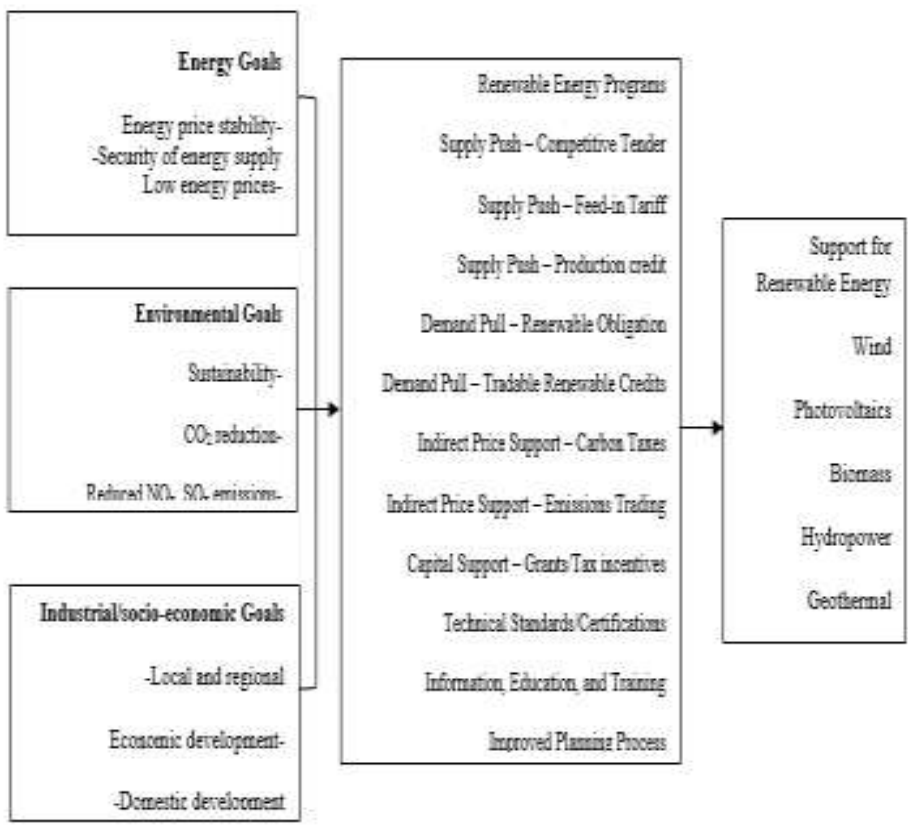

In another study done by Shen et al (2010), it is considered criteria as follow, and by applying AHP method it is highlighted as a proper renewable energies for Taiwan.

In a different research carried out by Shen et al (2010), it is tested the standards and measures as follow and by applying AHP method it is also emphasized suitable energies which is able to be restored and refreshed for Taiwan. 
Figure 2: Shen et al. 2010

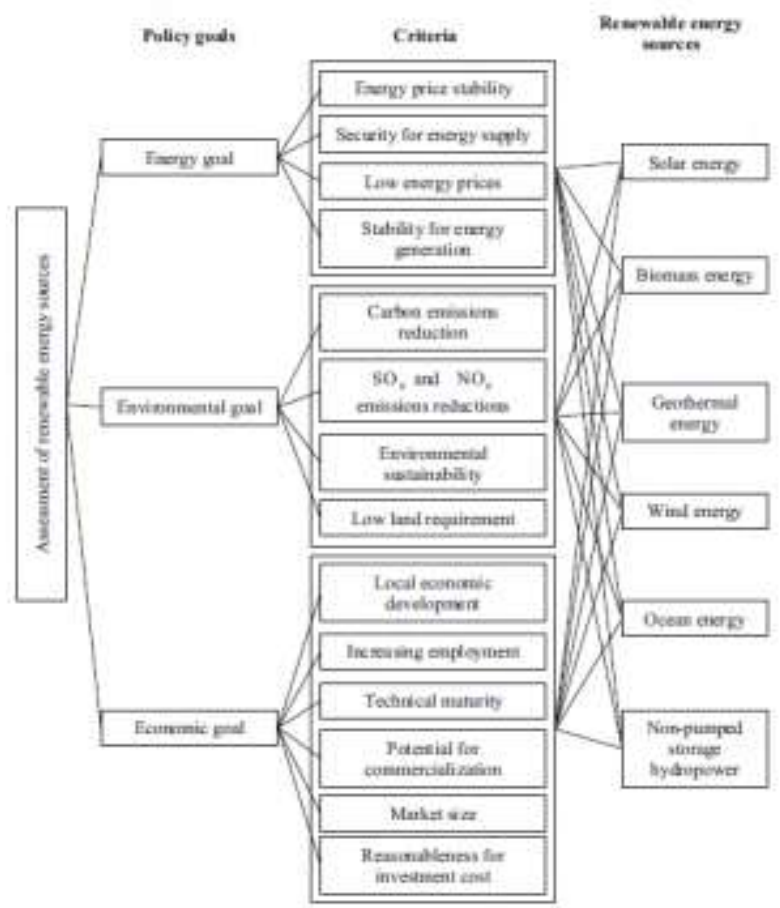

\subsection{Policy history}

The United Nation Framework Convention on Climate Change, With the goal of approaching the challenge of rapid growing worldwide greenhouse gases (GHGs), was constructed in 1992 and rehabilitated by the Kyoto Protocol in 1997 (Bishop,1997). The 2005/32/EC recipe and guidance, particularly the instruction of Eco-design need of Energy-using products (EUP), was legalized by European Union (European Commission, 2005) in response to the Kyoto Protocol. Based on EUP recipe and guidance, the act of importing products will be restricted and limited if the $\mathrm{CO} 2$ emissions inside of product be greater than the adjusted standard level (Huang, 2008).

Be based on National Energy Conference held in 2009, R\& D or in other words the study and advancement of renewable energy technologies and development in the industry of renewable energy should be dealt with and attended in the policy of renewable energy. Particularly, the progression of the renewable energy industry is now remarked as a strategy to create jobs and national quality of being competitive (Zohoori et al, 2012).

\subsection{Renewable energy potentials in Iran}

Based on Fadaei et al. (2011) there are five types of renewable energy sources in Iran as below:

\subsubsection{Hydropower}

As Zohoori 2012, at the moment, water is one of the most fundamental renewable energy resources in Iran, with potential for the production of electricity around 50 TWh. At the end of 2007, based on Iran's ministry of energy, total capacity of functioning hydroelectric power plants was $7422.5 \mathrm{MW}$.

\subsubsection{Wind energy}

Wind is the second source of renewable energy in generation of electricity in Iran. According to the investigation done by (SUNA, 2009), Iran is a country with $6 \mathrm{~m} / \mathrm{s}$ average wind speed. There are regions in some parts of the country which are more proper for generation of electricity through wind.

Iran is placed in the major air flow path amongst Asia, Europe, Africa, Indian Ocean and the Atlantic Ocean and thus is subject to:

- Pressure center flow over central Asia in winter;

- Pressure center flow over Indian Ocean in summer;

Figure 3: Generation of wind power in 2001-2007 published by energy ministry 2007.



-Western flow from Atlantic and the Mediterranean Sea, especially in winter;

- Northwest flow during summer published by SUNA 2009;

Figure 3 represents which wind power generation was around 140million $\mathrm{kWh}$ in 2007 , and the government has begun implementing strategy to support private sector in this field.

\subsubsection{Solar energy}

Iran is placed on world's Sun Belt enjoys around 2800 sunny hours per year. Based on (http: //www.suna.org/.) its solar insulation average is estimated as 2000 
$\mathrm{kWh} / \mathrm{m} 2$ year, As a result of this, Iran has a suitable status for solar energy utilization. Besides, by consumption of just one percent of this source of energy in Iran, It can procure all its required energy (SUNA, 2009). According to statistical reports, total installed valence of photovoltaic electricity generation systems in function in Iran is $175 \mathrm{~kW}$. In 2007, about 71,000 kWh of electricity was produced by Tehran $30 \mathrm{~kW}$ photovoltaic power plant and Darbid Yazd and Sarkavir Semnan power plants respectively. (Energy Ministry; 2007). Figure 5 represents solar PV off-grid electricity generation trend between 2001 and 2007. In addition, there are some activities which have been carried out in the field of solar and thermal system application in Iran such as, manufacturing of the prime phase of Shiraz solar thermal power plant with a capacity of $250 \mathrm{~kW}$ which is considered as one of the most fundamental plans, but in order to previous projects, this one should be completed until the end of fourth national development plan, however its vapor phase has been implemented until now. Another activity is this field is the installation of nearly 18,000 solar water heaters for household utilization and offices based on (Energy Ministry; 2007). However, no solar heaters was installed in Iran in 2007 (Zohoori et al, 2012).

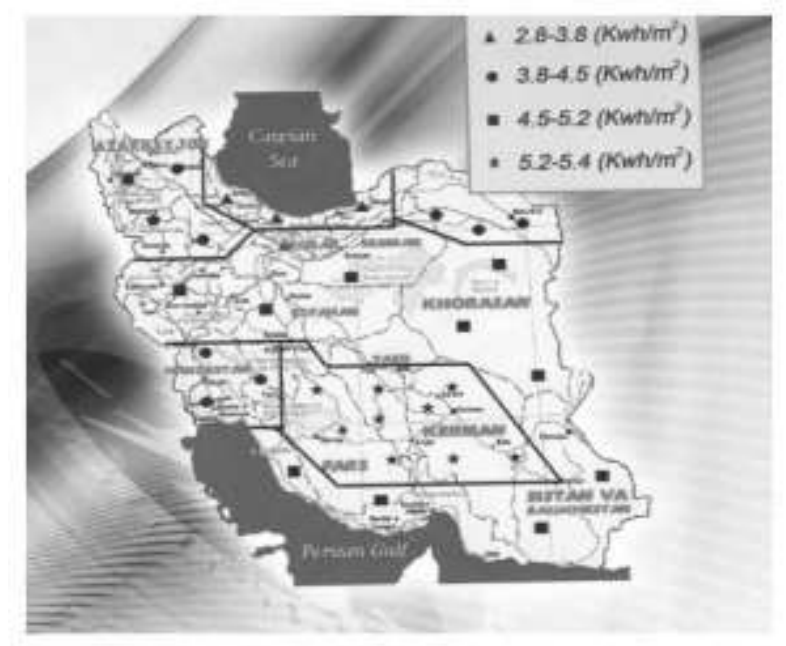

During Iran's third and fourth national development plan, approximately $77,000 \mathrm{~m}^{2}$ of solar collectors were installed (Energy Ministry, 2006). Though, the activities and progressions of other countries such as Germany, Turkey and China in this field, stresses Iran's government that there is a lengthy road ahead of Iran to approach the designed purpose.

\subsubsection{Geothermal}

At present, there are some programs in Iran which are running in the field of exploitation of this potential.in Iran, Two main activities which are done in this field, are $60 \%$ progress of Meshkin-Shahr geothermal plant with a capacity of 370 million $\mathrm{kWh}$ each year, and $30 \%$ progress of Ardebil 3-5MW plant with a yearly generation capacity of 40 million $\mathrm{kWh}$ according to Energy Ministry 2007.

Figure 5: Solar off-grid PV electricity generation in 2001-2007 in Iran (Fadaei et al 2011).

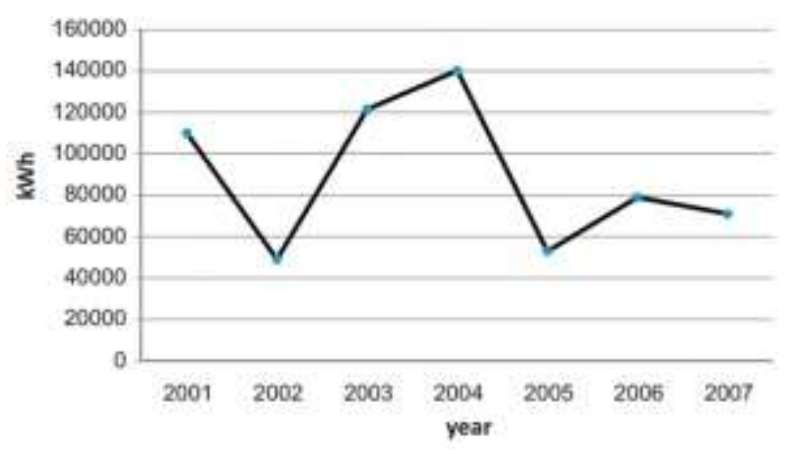

\subsubsection{Other renewable energy sources}

Iran's Ministry of also has done some activities with respect to other renewable sources including construction and operation of a $25 \mathrm{~kW}$ polymeric Fuel Cell as well as designing and manufacturing of a $5 \mathrm{~kg}$ polymeric fuel cell with the aim of approaching technical knowledge.(Energy Ministry; 2007)

Furthermore, some feasibility researches has been carried out on biogas generation in Saveh city $(600 \mathrm{~kW}$ power), Mashhad and Shiraz biomass power plants generate $650 \mathrm{~kW}$ and $1060 \mathrm{~kW}$ respectively. Likewise, it is predicted that the installation operations will soon start based on Energy Ministry; 2007.

Totally, a comprehensive evaluation of Iran's energy supply from renewable sources displays that the overall installed volume of renewable energy sources in Iran has reached more than $110 \mathrm{MW}$ up to now (Energy Ministry, 2006). The process of such changes in the installed volume in mid-2007 is explained in table 1.

Installed capacity in renewable energy sources between the years 1997 and 2007 


\begin{tabular}{|l|l|l|l|l|}
\hline & $\mathbf{1 9 9 7}$ & $\mathbf{2 0 0 0}$ & $\mathbf{2 0 0 3}$ & $\mathbf{2 0 0 7}$ \\
\hline Solar energy & & & & \\
\hline $\begin{array}{l}\text { Solar } \\
\text { photovoltaic }\end{array}$ & $\mathrm{KW}$ & $47 \mathrm{KW}$ & $\begin{array}{l}170 \\
\mathrm{KW}\end{array}$ & $175 \mathrm{KW}$ \\
\hline $\begin{array}{l}\text { Solar water } \\
\text { heater }\end{array}$ & - & - & 119 & $4132 \mathrm{KW}$ \\
\hline $\begin{array}{l}\text { Wind energy } \\
\text { KW }\end{array}$ & 1100 & $\begin{array}{l}10,100 \\
\mathrm{KW}\end{array}$ & $\begin{array}{l}11,800 \\
\mathrm{KW}\end{array}$ & $\begin{array}{l}73,990 \\
\mathrm{KW}\end{array}$ \\
\hline $\begin{array}{l}\text { Small } \\
\text { hydropower }\end{array}$ & $\begin{array}{l}\mathrm{KW} \\
\begin{array}{l}\text { KW } \\
\text { KW }\end{array}\end{array}$ & $\begin{array}{l}7740 \\
\mathrm{KW}\end{array}$ & $\begin{array}{l}9694 \\
\mathrm{KW}\end{array}$ & $\begin{array}{l}36,050 \\
\mathrm{KW}\end{array}$ \\
\hline $\begin{array}{l}\text { Total } \\
\text { renewable } \\
\text { energy } \\
\text { resources }\end{array}$ & $\mathrm{KW}$ & $\mathrm{KW}$ & $\mathrm{KW}$ & $\mathrm{KW}$ \\
\hline
\end{tabular}

\subsubsection{Socio-economic impacts of renewables}

The manufacturing of any energy power supply system contains the impact at various levels of the society. For example it makes impacts on the technical advancement, to the environment, to the local population as well as to the national economy. It is obvious that some of these impacts are so strict to examine but nonetheless, one should attempt to quantify or to identify the convincible impacts which a certain energy plant will have. Of course these kinds of impacts can be qualified as affirmative impacts under some viewpoints or minus impacts under other viewpoints. On the other hand, an impact can be considered positive or negative due to the opinion of actors. Some actors may not see the impact as such and choose simply to neglect it. For example, normally a renewable energy developer does not assume the impact of such renewable energy plants on the national economy, or how it affects to the various segments of the economy (Gro Waerras et al, 1998).

As Abrishami, et al, (2009) mentioned development of renewable energy has various economic and social interests for Iran. So from where that use of fossil fuels end in near future due to resource constraints in energy supply, this is a very important issue. Therefore, the lack of social and environmental costs are also positive aspects. Besides, the need to save fossil fuels and the use of renewable energy sources is something inevitable due to increasing need for energy and limitations fossil resources, increasing environmental pollution caused by the consumption of these resources, the issue of global warming and the greenhouse effect, acid rain and the need to balance the emission of carbon dioxide. In fact, in some countries the use of renewable energy in electricity generation, have managed to prevent the release of more than 100 million tons of carbon dioxide which is very substantial in reducing environmental pollutants and this is a clear example of the use of technologies of such energies.

On the other hand decentralized production of electricity from renewable energies capabilities has provided development opportunities for remote and rural areas of Iran which this matter strengthens social and economic structure of rural areas as well as prevent their migration to the cities. Furthermore, utilization of renewable energy has been fundamental in terms of employment. Employment status of these systems has been much more than job creation resulting from the use of fossil fuels due to their new nature as the use of these systems is possible for indigenous and local use. According to the conducted surveys installation, implementation, operation and maintenance process from renewable energy realized mainly in rural and deprived areas. Therefore, as regards such areas have higher unemployment rates and the function of these systems can be effective in living population stabilization of these areas. Besides, use of these kinds of energy sources will have a significant role in reducing deprivation as well as growth and productivity in Iran. In addition, effective role in passive defense has significant effects on the provision of appropriate infrastructure in the energy sector and also the country's current energy systems (Abrishami, et al, 2009)

Nowadays, it can be seen by investigation in the energy system features of Iran which lack of diversity in the use of these systems in three areas such as resources, productive technology and distribution network and high uncertainty in the energy system caused that the degree of energy security in the country has been at low 
levels thus, it's much more important for Iran which is located in a special area in terms of political, social and economic and military and also is looking for achieving the development goals.

Besides, the development and utilization of renewable energies can play a fundamental role in the increasing of the country's energy system security (Passive Defense). Because use of the infrastructure development of renewable energy sources of the country leads to:

1- The diversity of current energy sources

2- More adjustment with rules and regulations of environmental obstacles

3- Diversity in energy production technology

4- Help to eliminate hot spots Electric power transmission network in oil facilities.

Plus, development of renewable energy function can promote national security, because by examining the prospects for the next 20 years it is observed that a significant part of GDP will be provided through export of fossil energy carriers. However, it is possible to produce energy, to help to maintain continuity of energy exports and protect resources of fossil fuels for future generations with the development of renewable energy (Abrishami, et al, 2009).

\subsubsection{Environmental impacts of} renewables

It is crucial to find out the environmental impacts associated with the production of power from renewable sources such as hydropower, biomass, solar, geothermal and wind. The precise type and intensity of environmental impacts differs depending on the characteristic of the technology used, the geographic location and a number of various factors.

Different aspects of the impact of renewable energy sources can be analyzed including amongst others: water and air emissions, generations of waste particularly hazardous materials, generation of noise, land use, global warming emissions. Besides, by realizing the ongoing and potential environmental issues associated with each renewable energy sources, it is possible to take steps to avoid or minimize these impacts as they become a greater portion of Iran's electric supply (Ewa Klugmann-Radziemska, et al, 2014).

An entire series of determinants are favoring the advancement of energy sector according to renewable resources: rising social awareness of the need to restrict harmful materials emission, legislation, pro-environmental strategy of governments, by-laws and regulation, support in the form of programs and fiscal mechanisms, not to mention the increasing prices of energy from conventional sources and the need to ensure security of energy (Ewa Klugmann-Radziemska, et al, 2014).

Since the environmental function and performance of renewable energy systems is considerably developed by: increased efficiency and longer lifetime, both should be motivated for the devices and entire systems. In most countries, industrial improvement is conditional on the developer to obtain a legal permission from a regulatory authority which contains evaluating of the impact of the development which may have on the environment. Preservation of the environment is not only a local issue, but also it is an international concern (Ewa Klugmann-Radziemska, et al, 2014).

The concise comparison between environmental advantages and costs of the utilization of various types of RES is demonstrated in the Fig. 6 and Table 2.

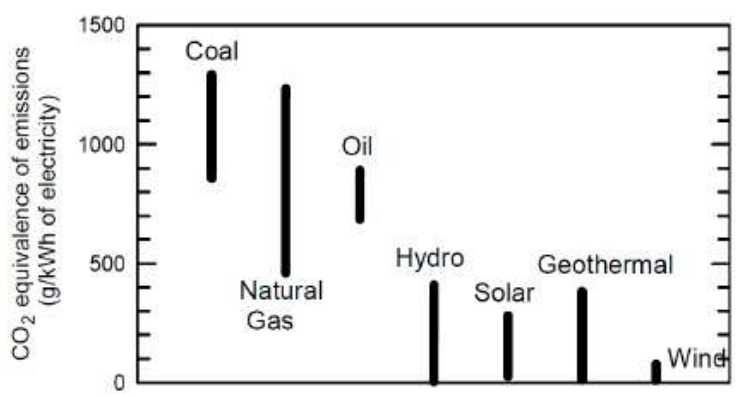

Fig 6: Relevant amounts of greenhouse gases emissions from different types of electricity generation techniques, data are expressed as $\mathrm{CO}_{2}$ equivalents (Ewa Klugmann-Radziemska, et al, 2014).

Table 2: Analogy between environmental advantages and expenses. 


\begin{tabular}{|c|c|}
\hline $\begin{array}{l}\text { Environmental } \\
\text { benefits }\end{array}$ & Environmental costs \\
\hline $\begin{array}{l}\text { Energy produced } \\
\text { by the renewable } \\
\text { energy systems }\end{array}$ & $\begin{aligned} & \text { Production of devices and BOD } \\
& \bullet \text { Greenhouse gas } \\
& \text { emissions } \\
& \bullet \text { Heavy metals } \\
& \text { emissions } \\
& \bullet \text { Energy used } \\
& \text { (Energy pay-back } \\
& \text { time) } \\
& \text { Wastes generated by different RES } \\
& \text { industry }\end{aligned}$ \\
\hline
\end{tabular}

At the present time, Iran has implemented some strategies and policies and incentives to rise the share of renewable energies in order to progress energy security and decrease environmental pollution and build new job opportunities. The strategy and measures can be classified into 3 groups: fiscal supports, knowledge progression, infrastructures, funds, and power purchase agreement tariffs. The volume of constructed and connected renewable energy power plants are displayed in the following table for the end of the year in Iran.

Table 3: Iran Renewable Energy Power capacity - MW (http://www.howtoinvestiniran.com/2305-2/)

\begin{tabular}{|c|c|c|c|c|c|c|c|c|c|c|}
\hline Srifedaty & 2196 & $2 W^{2}$ & 2118 & Sy & MII0 & 201 & 2012 & 205 & 214 & 205 \\
\hline Lage Fytopone & 6,533 & 7344 & 764 & 7656 & 8434 & 864 & 9,76 & 10365 & $12 \times 2$ & 12,88 \\
\hline Oethore Tind & $\$ 9$ & 74 & $y_{0}$ & 91 & 3 & 98 & 98 & 98 & 117 & II) \\
\hline Matun II tropous & 36 & 36 & 46 & 4 & 51 & 60 & 60 & 68 & 65 & 65 \\
\hline Coosertuted Solar Poure & & & 0 & 17 & 17 & 17 & 17 & 17 & 17 & 17 \\
\hline Sonalligitopone & 3 & 3 & 3 & 3 & 3 & 3 & 3 & 3 & 3 & 3 \\
\hline $\begin{array}{l}\text { Prrogd Strnge ad Ifred } \\
\text { Parts }\end{array}$ & & & & & & & & & & 1140 \\
\hline Tote & 6.631 & 7,437 & 7763 & 7812 & 8738 & 8162 & 99.4 & 3046 & 19Q4 & 12004 \\
\hline
\end{tabular}

Iran's total primary energy consumption, share by fuel 2013 .

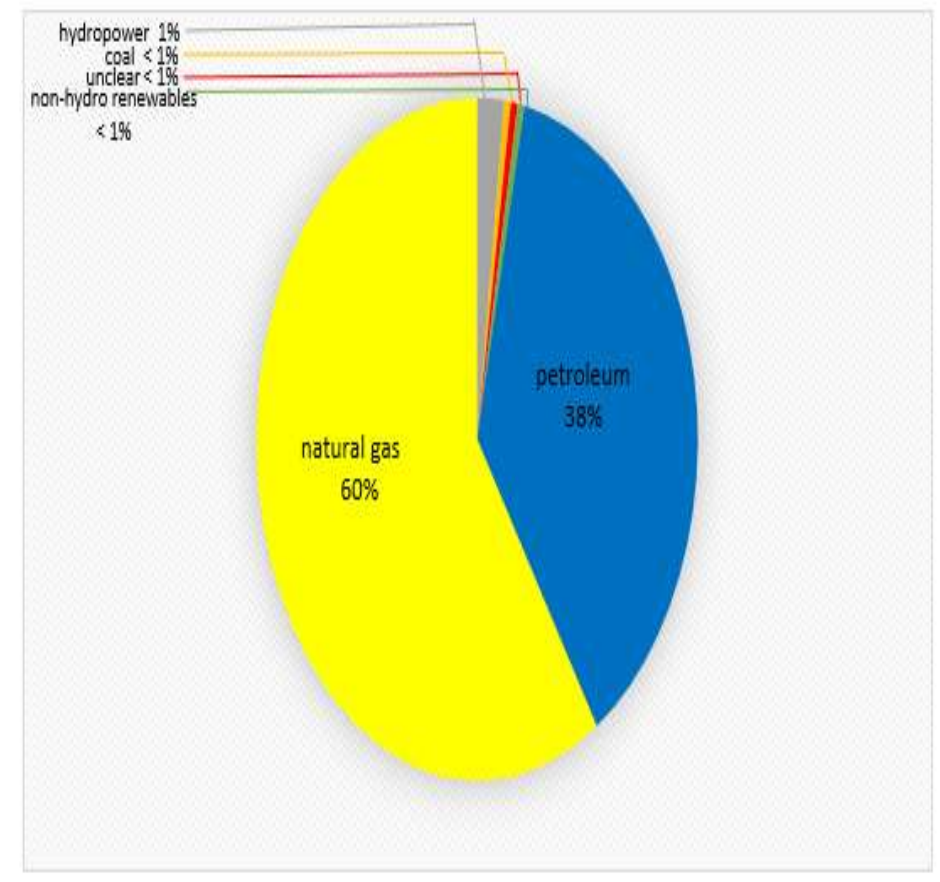

Figure 7: Source: U.S. Energy Information Administration, Frost \& Sullivan (2015).

\section{PROPOSED METHOD}

There are large number of complex logical methods to be utilized in order to study for the most desirable response for multi-purpose difficulties. (Greening and Bernow, 2004). One of the best and most reliable, wellknown and great procedures and techniques is the analytic hierarchy process (AHP) found and established by Saaty (1980). However, uncertainty and absence of clarification in many examples is found between the evaluations of decision-makers concerning the problems which seek to deal with. Fuzzy combines with AHP to constitute fuzzy AHP recognized as FAHP and is employed to assess and measure the uncertainty and absence of clarification which exists in the valuation of the decision-makers subjective (Zohoori et al 2012).

The proposed framework of this study is approximately similar to Shen et al framework (2010) (figure 2). However, the renewable sources must be replaced with a 5 sources suggested by Fadaei et al. (2011).

Analytic Hierarchy Process or in other words AHP proposed by Saaty (1980) illustrates and interprets the procedures of deciding the preliminary issue of a set of standards and parameters and the comparative significance of a multi-criteria decision making (MCDM) obstacle amongst them (Saaty, 1980; Wei et 
al., 2005; Hu et al., 2009). The major profit of AHP is to conduct multiple standards and measures and doing quantitative along with qualitative data analyses quickly and easily (Meade and Sarkis, 1998; Kahraman et al., 2004). Thus, there are some surveys which have used analytic hierarchy process (AHP) during their planning for renewable energy for example maintainable advancement of rural energy in China (Wang and Feng, 2002), the recruitment of techniques and technologies concerning solar energy in Jordan (Elkarni and Mustafa, 1998), evaluation of renewable energy plants (Chatzimouratidis and Pilavachi 2008.2009) as well as renewable energy planning in South Korea (Lee et al., 2007).

The field of detecting energies which can be renewed and those who are residents of Iran. Furthermore, experts and professionals with high reputation and ranking in the government, or manufacturing line or universities and colleges, are going to be exclusively considered for this study. It has to be mentioned that the size was estimated prior to the Shen et al. (2010)'s survey.

\section{CONCLUSION}

Nowadays more than ever, the focus of governments of all countries is based on issues concerning environments. In connection with the point formerly mentioned, governments are obliged to test the purpose and intention of socio-economic as well as required and imperative energies. According to global view, International Energy Agency (IEA) (2004) proposed that energy which is able of being renewed is evaluate by large number of policy-makers in countries which are members of IEA as a tools to participate to enhance environmental protection, socio-economic improvement, energy security, recognized as 3 Es. In this regard, there is a high potential for utilizing and exploiting renewable energy sources in Iran too. Be based on Fadaei et al. (2011) there are five sources including Geothermal, Solar, Wind, Hydropower, and others. Thus, it is possible to rank these sources by applying AHP method based on 3Es' goals.

\section{REFERENCES}

Abolhosseini et al, 2014. "A Review of Renewable Energy Supply and Energy Efficiency Technologies" Discussion Paper No. 8145.

Abrishami, et al, (2009), Energy economic studies (15) Institute for International Energy Studies.

Azam Mohamadi (2016), "Opportunities for Investment in Renewable Energies" Iran Renewable" website (http://www.howtoinvestiniran.com/2305-2/).

Beccali, M., Cellura, M., Mistretta, M., 2003. Decisionmaking in energy planning: application of the Electre method at regional level for the diffusion of renewable energy technology. Renewable Energy 28 (13), 2063 2087.

Bishop, B.L., 1997. Pollution Prevention: Fundamental sand Practice. McGraw-Hill, New York

Cai, Y.P., Huang, G.H., Tan, Q.,Yang, Z.F., 2009a. Planning of community-scale renewable energy management systems in a mixed stochastic and fuzzy environment. Renewable Energy 34 (7), 1833-1847.

Chatzimouratidis, A.I., Pilavachi, P.A., 2008. Sensitivity analysis of the evaluation of power plants impact on the living standard using the analytic hierarchy process. Energy Conversion and Management 49 (12), 3599-3611.

Energy Balance Sheet. Department of Electrical and Energy Department of Energy Ministry; 2007.

Elkarni, F., Mustafa, I., 1998. Increasing the utilization of solar energy technologies (SET) in Jordan: analytic hierarchy process. Energy Policy 21 (9), 978-984

Ewa Klugmann-Radziemska (2014), "Environmental Impacts of Renewable Energy Technologies"., 2014 5th International Conference on Environmental Science and Technology IPCBEE vol.69 (2014) C (2014) IACSIT Press, Singapore DOI: 10.7763/IPCBEE. 2014. V69. 21.

European Commission, 2005. Directive2005/32/Ec of the European Parliament and of the Council Establishing a Framework for the Setting of Ecodesign Requirements for Energy using and Amending Council Directive 92/42/EEC and Directives 96/57/EC and 2000/55/EC of the European Parliament and of the Council. European Commission, Strasbourg.

Fadai, D., Sfandabadi, Z. Sh, Abbasi, A., (2011) Analyzing the causes of non-development of renewable energy-related industries in Iran, Renewable and Sustainable Energy Reviews 15 (2011) 2690-2695. 
Frost \& Sullivan. "Iran is on an Aggressive Growth Path to Develop Renewable Energy to Manage with Capacity Shortages, notes Frost \& Sullivan," December 2015. http://ww2.frost.com/news/press-releases/iran-aggressivegrowth-path-dev.

Greening, L.A., Bernow, S., 2004. Design of coordinated energy and environmental policies: use of multi-criteria decision-making. Energy Policy 32 (6), 721-735.

Gro Waerras et al (1998), "The socio-economic impact of renewable energy projects in southern Mediterranean countries", Task 5- INTERSUDMED Project), Work performed in partial fulfilment of the Joule contract no JOR-CT95-0066.

Huang, L., 2008. The global trend of green procurement. Quality Magazine 44 (8), 36-40.

International Energy Agency, 2004. Renewable Energy: Market \& Policy Trends in IEA Countries. International Energy Agency, Paris.

Kahraman, C., Cebeci, U., Ruan, D., 2004. Multi-attribute comparison of catering service companies using fuzzy AHP: the case of Turkey. International Journal of Production Economics 87 (2), 171-184.

Komor, P., Bazilian, M., (2005), Renewable energy policy goals, programs, and technologies, Energy Policy 33 (2005) 1873-1881.

Lee, S.K.,Yoon,Y.J., Kim,J.W., 2007. A study on making a long-term improvement in the national energy efficiency and GHG control plans by the AHP approach. Energy Policy 35 (5), 2862-2868.

Meade, L., Sarkis, J., 1998. Strategic analysis of logistics and supply chain management systems using analytic network process. Transportation Re-search Part E: Logistics and Transportation Review 34 (3), 201-215.

M. Zohoori (2012), "Exploiting Renewable Energy Sources in Iran"., Interdisciplinary Journal Of Contemporary Research In Business, ISSN 2073 7122, November Vol .4, No.7.

Onut, S.,Tuzkaya, U.R. , Saadet, N., 2008. Multiple criteria evaluation of current energy resources for Turkish manufacturing industry. Energy Conversion and Management 49 (6), 1480-1492.
Renewable Energy Organization of Iran (SUNA) website, http://www.suna.org/.

Renewable Energy Organization of Iran (SUNA) report collections, "what do you know about renewable energy? Wind Energy"; 2009.

Renewable energy in Islamic Republic of Iran, Iran Ministry of energy, Presented in renewable energy conference 2006, Japan.

Saaty, T.L., 1980.The Analytic Hierarchy Process. McGraw-Hill, New York.

Shen, Yung-Chi, Grace T.R.Lin, Kuang-PinLi, Benjamin J. C. Yuan (2010), An assessment of exploiting renewable energy sources with concerns of policy and technology, Energy Policy 38(2010)46044616.

Word energy scenario, Iran Energy Balance Report. Iran's Ministry of Energy; 2008.

Wei, C.C.,Chien,C.F.,Wang, M.J., 2005. An AHP-based approach to ERP systems election. International Journal of Production Economics 96, 47-62. 